\title{
MENINGKATKAN KEMAMPUAN BERPIKIR KREATIF MATEMATIS SISWA SMA MELALUI PEMBELAJARAN INKUIRI BERBANTUAN SOFTWARE GEOGEBRA PADA POKOK BAHASAN PROGRAM LINEAR
}

\author{
Muhammad Rizal Usman ${ }^{1}$, St. Nur Humairah Halim² \\ Universitas Muhammadiyah Makassar, Makassar \\ ${ }^{1}$ rizal.usman@unismuh.ac.id
}

\begin{abstract}
Abstrak
Penelitian ini merupakan penelitian eksperimen kuasi. Populasi penelitian ini adalah seluruh siswa kelas XII tahun ajaran 2017/2018, dengan mengambil dua kelas untuk dijadikan kelas eksperimen (XII IPA2) dengan jumlah siswa 37 orang dan kelas kontrol (XII IPA4) dengan jumlah 36 orang. Tujuan penelitian ini adalah untuk (1) mengetahui pencapaian kemampuan berpikir kreatif siswa melalui pembelajaran inkuiri berbantuan software Geogebra software GeoGebra pada pokok bahasan program linear, dan (2) mengetahui peningkatan kemampuan berpikir kreatif siswa melalui pembelajaran inkuiri berbantuan software Geogebra software GeoGebra pada pokok bahasan program linear. Berdasarkan analisis data, hasil penelitian dan pembahasan diperoleh simpulan penelitian sebagai berikut: 1) Pencapaian dan peningkatan kemampuan berpikir kreatif matematis siswa yang belajar dengan pembelajaran inkuiri berbantuan software Geogebra lebih baik daripada siswa yang memperoleh pembelajaran konvensional. Rerata skor postes pada kelas inkuiri berbantuan software Geogebra dan konvensional yaitu 9,70 (60,63\%) dan 7,84 (49,01\%), dari rerata skor postes kemampuan berpikir kreatif matematis siswa inkuiri berbantuan software Geogebra lebih tinggi daripada kelas konvensional. Untuk n-gain kelas inkuiri berbantuan software Geogebra lebih tinggi daripada kelas konvensional yaitu masing-masing 0,41 berada dalam kategori sedang dan 0,23 berada dalam kategori rendah. Dan 2) kegiatan pembelajaran di kelas yang memperoleh pembelajaran inkuiri software Geogebra sudah terlaksana dengan baik. Walaupun pada awal pertemuan masih dibutuhkan waktu penyesuaian, akan tetapi pada pertemuan selanjutnya pembelajaran berlangsung sesuai dengan langkah-langkah yang telah ditentukan
\end{abstract}

Kata Kunci: kemampuan berpikir kreatif, model inkuiri, Geogebra

\begin{abstract}
This research is a quasi experimental study. The population of this study were all students of class XII 2017/2018 academic year, taking two classes to be used as experimental class (XII IPA2) with 37 students and control class (XII IPA4) with 36 students. The purpose of this study was to (1) find out the achievement of students 'creative thinking abilities through GeoGebra software assisted inquiry learning on the subject of linear programs, and (2) find out the improvement of students' creative thinking skills through assisted inquiry learning Geogebra software GeoGebra software on the subject of linear programs. Based on data analysis, the results of research and discussion obtained the following conclusions: 1) Achievement and improvement of mathematical creative thinking skills of students who learn with
\end{abstract}


Geogebra software assisted inquiry learning better than students who obtain conventional learning. The mean posttest scores on Geogebra and conventional software assisted inquiry classes were $9.70(60.63 \%)$ and $7.84(49.01 \%)$, from the mean posttest scores of Geogebra software students' mathematical creative thinking abilities than conventional classes. For n-gain, the Geogebra software-assisted inquiry class is higher than the conventional class, which is 0.41 in the medium category and 0.23 in the low category and 2) learning activities in the classroom that get Geogebra software inquiry learning have been carried out well. Although at the beginning of the meeting there is still a need for adjustments, at the next meeting learning takes place in accordance with the prescribed steps

Keywords: creative thinking skills, inquiry model, Geogebra

\section{Pendahuluan}

Kemampuan berpikir kreatif merupakan salah satu kemampuan berpikir tingkat tinggi yang kini sudah menjadi pusat perhatian guru dalam pembelajaran matematika. Tetapi dilapangan masih menunjukkan kurangnya optimal perkembangan dari kemampuan berpikir kreatif siswa. Seperti yang dikemukakan oleh Munandar (dalam Sri, 2009) perkembangan optimal dari kemampuan berpikir kreatif berhubugan erat dengan cara mengajar, dalam suasana non-otoriter, proses belajar akan berlangsung atas prakarsa sendiri. Ketika guru dapat memberi kepercayaan kepada siswa baik dalam mengemukakan pendapat atau memberikan kesempatan kepada siswa untuk mengerjakan tugas sesuai dengan kebutuhannya. Suasana ini, dapat memberikan efek positif dalam mengembangkan kemampuan berpikir kreatif siswa.

Untuk memunculkan sikap kreatif siswa, dibutuhkan suatu model pembelajaran yang sesuai dan betul-betul memberikan kontribusi yang baik dalam peningkatannya. Dalam menggunakan model pembelajaran yang baik dan menarik dalam proses belajar membantu siswa lebih tenang dalam menerima materi pelajaran. Ketidaksesuaian model pembelajaran yang diterapkan terkadang menimbulkan kebosanan siswa, dan siswa kurang memahami materi. Oleh karena itu. Seorang guru seharusnya jelih dalam memilih dan memilah model pembelajaran untuk kemampuan berpikir kreatif siswa. Berdasarkan hasil observasi dan wawancara dengan guru matematika SMA Negeri 3 Makassar kelas XII, jelas bahwa beberapa faktor yang mempengaruhi proses pembelajaran salah satunya kurang tepatnya guru dalam memilih model pembelajaran yang sesuai dengan materi ajar. Perlu diperhatikan, tidak semua materi ajar guru yang harus menerangkan di depan kelas, tetapi bagaiman melibatkan siswa dalam proses belajar tersebut.

Terkait meningkatkan kemampuan berpikir kreatif siswa, perlu dikaji juga penguasan siswa terhadap komputer. Dalam penelitian ini akan menjelaskan tentang kemampuan berpikir kreatif siswa dengan menggunakan aplikasi matematika sebagai media pembelajaran, yaitu salah aplikasinya adalah geogebra. Perkembangan komputer yang pesat sangat berdampak baik pada pembelajaran matematika. Geogebra merupakan salah satu aplikasi komputer gratis yang dapat dimanfaatkan sebagai media pembelajaran terkhusus pada materi Program Linear. Geogebra digunakan sebagai media bantu untuk menjelaskan tentang konsep daerah dan menyelesaikan masalah pemrograman linear. Berdasarkan analisis di atas, peneliti akan melakukan penelitian dengan judul sebagai berikut: "Meningkatkan Kemampuan Berpikir Kreatif Matematis Siswa SMA Melalui 
Pembelajaran Inkuiri Berbantuan Software Geogebra Pada Pokok Bahasan Program Linear".

Berdasarkan latar belakang di atas maka rumusan masalah dalam penelitian ini adalah 1) Apakah pencapaian kemampuan berpikir kreatif matematis siswa yang belajar melalui pembelajaran inkuiri berbantuan software Geogebra lebih baik daripada siswa yang memperoleh pembelajaran konvensional? Dan 2)Apakah peningkatan kemampuan berpikir kreatif matematis siswa yang belajar melalui pembelajaran inkuiri berbantuan software Geogebra lebih baik daripada siswa yang memperoleh pembelajaran konvensional.

Torrance (Hendrayana, 2008) mengemukakan tiga komponen yang menjadi bagian dari kemampuan berpikir kreatif, yaitu (1) Fluency (kelancaran), yaitu menghasilkan banyak ide dalam berbagai kategori/bidang; (2) Originality (keaslian), yaitu mempunyai ide-ide baru untuk memecahkan persoalan; dan (3) Elaboration (penguraian), yaitu kemampuan memecahkan masalah secara detail. Kreativitas dalam matematika sangat penting, ini didukung oleh Bishop (Pehnoken, 1997) yang menyatakan bahwa seseorang memerlukan dua keterampilan berpikir matematis, yaitu berpikir kreatif yang sering dikaitkan dengan intuisi dan kemampuan berpikir analitik yang dikaitkan dengan kemampuan berpikir logis. Sementara Krutetski (Park, 2004) mendefinisikan kemampuan berpikir kreatif matematis sebagai kemampuan menemukan solusi masalah matematika secara mudah dan fleksibel. Pendapat lain, yaitu Kiesswetter (Phnoken, 1997) menyatakan kemampuan berpikir fleksibel yang merupakan salah satu komponen kreativitas adalah kemampuan penting yang harus dimiliki siswa dalam menyelesaikan masalah matematika. Pendapat-pendapat ini menekankanpada eksistensi dari kemampuan berpikir matematis.

Kartini (2011) mendefinisikan kemampuan berpikir kreatif matematis adalah kemampuan memecahkan masalah tidak rutin dalam matematika yang mencerminkan aspek: kepekaan, kelancaran, keluwesan, dan kebaruan/keaslian serta kemampuan mengelaborasi. Kepekaan adalah kemampuan mendeteksi dan menanggapi masalah. Kelancaran adalah kemampuan memberikan lebih dari satu ide yang relevan dalam memecahkan masalah. Keluwesan adalah kemampuan memecahkan masalah dengan berbagai cara atau dengan cara yang beragam. Kebaruan/keaslian adalah kemampuan memecahkan masalah dengan cara yang tidak biasanya/unik atau dengan caranya sendiri. Elaborasi adalah kemampuan melengkapi dan merinci situasi masalah secara detail.

Pembelajaran Inkuiri pertama kali diperkenalkan dan dikembangkan oleh Richard Suchman (dalam Apiati, 2012) yang bertujuan untuk melibatkan para pelajar dalam proses penalaran mengenai hubungan sebab akibat dan menjadikan mereka lebih fasih dan cermat dalam mengajukan pertanyaan, membangun konsep dan merumuskan serta mengetes hipotesisi. Inkuiri pada dasarnya adalah cara menyadari apa yang telah dialami. Karena itu, inkuiri menuntut peserta didik berpikir. Sasaran utama kegiatan pembelajaran inkuiri ini adalah (1) keterlibatan siswa secara maksimal dalam proses kegiatan belajar; (2) keterarahan kegiatan secara logis dan sistematis pada tujuan pembelajaran pembelajaran; dan (3) mengembangkan sikap percaya diri siswa tentang apa yang ditemukan dalam proses inkuiri.

Salah satu software atau aplikasi yang dapat digunakan sebagai media pembelajaran matematika yaitu Geogebra. Aplikasi ini dikembangkan oleh Markus Hohenwarter pada tahun 2001. Menurutnya, geogerbra merupakan program komputer gratis yang dirancang untuk menggabungkan geometri, kalkulus, alabar dalam satu lingkunan yang dinamis. Program bisa diunduh di http://www.geogebra.org. Dari beberapa penelitian menunjukkan bahwa geogebra dapat mendorong proses eksperimen siswa. Dengan pemanfaaran media ini siswa mendapatkan pengalaman, dan siswa mandiri mengkonstruk konsep secara umu. 
Dalam penelitian Yilmaz (2011), menunjukkan bahwa pembelajaran trigonometri berbantuan software Geogebra geogebra lebih efektif. Pemanfaatn program geogebra memberikan beberapa klebihan, diantaranya: a) lukisan geometri dihasilkan lebih cepat dan teliti, 2) terdapat fasilitas animasi dan gerakan-gerakan manipulasi, dan 3) dimanfaatkan siswa sebagai bahan evaluasi untuk mengecek kembali lukisan yang siswa buat.

\section{Metode Penelitian}

Penelitian ini didesain dalam jenis eksperimen kuasi dengan desain kelompok kontrol pretes-postes, untuk menjawab pertanyaan dalam penelitian ini, yaitu untuk sejauh mana pengaruh pembelajaran inkuiri berbantuan software Geogebra terhadap peningkatan kemampuan berpikir kreatif matematis siswa.

Penelitian ini diambil sampel pada dua kelas yang homogen dengan tindakan yang berbeda. Pada kelompok pertama, akan diberikan pembelajaran dengan metode inkuiri berbantuan software Geogebra (X), dan pada kelompok kedua akan diberikan tindakan dengan pembelajaran konvensional. Sehingga, desain eksperimen (Sugiyono, 2012) dalam penelitian ini dapat digambarkan sebagai berikut:

$\begin{array}{lll}\mathrm{O} & \mathrm{X} & \mathrm{O} \\ \mathrm{O} & & \mathrm{O}\end{array}$

Keterangan:

$\mathrm{X}=$ Pembelajaran matematika menggunakan pembelajaran inkuiri

$\mathrm{O}=$ Pretes dan postes kemampuan berpikir kreatif matematis

Populasi penelitian ini adalah seluruh siswa kelas XII tahun ajaran 2017/2018, dengan mengambil dua kelas untuk dijadikan kelas eksperimen (XII IPA2) dengan jumlah siswa 37 orang dan kelas kontrol (XII IPA4) dengan jumlah 36 orang. Sampel dipilih siswa kelas XII berdasarkan pertimbangan, bahwa mereka dianggap sudah bisa beradaptasi dengan pembelajaran baru yang berbeda dengan pembelajaran konvensional. Tahapan penelitian ini terdiri atas empat bagian, yaitu: (1) tahap persiapan, (2) tahap pelaksanaan, (3) tahap analisis data, dan (4) tahap pembuatan kesimpulan

\section{Hasil dan Pembahasan \\ Hasil}

Data kuantitatif diperoleh melalui hasil pretes dan postes kemampuan berpikir kreatif matematis pada awal dan akhir pembelajaran. Untuk pretes kemampuan berpikir kreatif diadakan sebelum pembelajaran diberikan, tujuannya untuk mengetahu kemampuan awal siswa kelas kontrol dan eksperimen, Pencapaian kemampuan berpikir kreatif matemati siswa dapat dilihat dari rerata nilai postes yang dicapai antara kedua kelas. Sedangkan peningkatan kemampuan berpikir kreatif matematis siswa dilihat dari skor gain ternormalisasi (N-gain) antara kedua kelas, serta kategori kemampuan awal matematisnya. Data diperoleh dari 73 siswa, terdiri dari 37 siswa kelas eksperimen dan 36 siswa kelas kontrol. Berikut ini disajikan gambaran umum data hasil pretes, dan $\mathrm{N}$-gain dari kemapuan berpikir kreatif matematis siswa. 
Tabel 1. Data Rerata Hasil Pretes, Postes/Posskala, dan N-gain Kemampuan Berpikir Kreatif Matematis

\begin{tabular}{ccccccc}
\hline \multirow{2}{*}{ Data Statistik } & \multicolumn{3}{c}{ Inkuiri Berbantuan Software } & \multicolumn{3}{c}{ Konvensional } \\
& Pretes & Postes & N-gain & Pretes & Postes & N-gain \\
\hline \multirow{x}{*}{$\bar{x}$} & 5,35 & 9,70 & 0,41 & 5,23 & 7,84 & \\
& $33,82 \%$ & $60,63 \%$ & & $32,32 \%$ & $49,01 \%$ & 0,23 \\
SD & 0,76 & 1,72 & 0,10 & 0,95 & 1,57 & 0,18 \\
\hline
\end{tabular}

Tabel $1 \mathrm{di}$ atas menunjukkan bahwa rerata nilai pretes kemampuan berpikir kreatif matematis kelas eksperimen dan kelas kontrol masing-masing adalah 5,35 dan 5,23. Terlihat bahwa rerata pretes kelas eksperimen lebih tinggi walau tidak signifikan dari kelas kontrol sebelum diberi perlakuan. Setelah pembelajaran, siswa kelas eksperimen mencapai 9,70 dan memperoleh peningkatan 0,41 yang tergolong sedang, begitu juga kelas kontrol yang mencapai 7,84 dan memperoleh peningkatan 0,23 yang tergolong rendah. Dari perolehan rerata postes dan $\mathrm{N}$-gain, terlihat bahwa kemampuan berpikir kreatif matematis siswa yang pembelajarannya menggunakan pembelajaran inkuiri dengan berbantuan software Geogebra lebih baik di banding siswa yang menggunakan pembelajaran konvensional.

Analisis data postes dilakukan untuk mengetahui apakah terdapat perbedaan yang signifikan antara kemampuan siswa kelas eksperimen dan kelas kontrol setelah diberi perlakuan. Analisis data dilakukan dengan uji perbedaan rerata. Untuk memilih jenis uji perbedaan rerata yang akan dipakai, terlebih dahulu dilakukan uji prasayart. Uji prasayarat yang dimaksud adalah uji normalitas data dan uji homogenitas varians. Uji normalitas data menggunakan uji Kolmogorov-Smirnov, sedangkan untuk uji homogenitas varians menggunakan uji Levene. Uji normalitas dilakukan dengan menggunakan uji KolmogorovSmirnov. Pada tabel 2 menunjukkan bahwa salah satu kelompok pembelajaran memperoleh nilai signifikansi yang lebih kecil dari $\alpha=0,05$, yakni 0,015 . Karena nilai signifikansi kelompok eksperimen lebih kecil dari $\alpha$, maka Ho ditolak. Artinya, data postes berpikir kreatif matematis siswa pada kelas eksperimen berasal dari populasi yang tidak berdistribusi normal. Hasil perhitungan uji normalitas disajikan pada tabel 2 berikut.

Tabel 2. Uji Normalitas Rerata PostesKemampuan Berpikir Kreatif Matematis

\begin{tabular}{cccccc}
\hline \multirow{2}{*}{ Kelas } & \multicolumn{4}{c}{ Kolmogorov-Smirnov } & \multirow{2}{*}{ Kesimpulan } \\
& $\mathrm{N}$ & Statistik & Sig. & Ket. & \multirow{2}{*}{ Berdistribusi tidak normal } \\
Eksperimen & 37 & 0,163 & 0,017 & $\mathrm{H}_{\mathrm{o}}$ Ditolak & Berdistribusi normal \\
Kontrol & 36 & 0,124 & 0,157 & $\mathrm{H}_{\mathrm{o}}$ Diterima & . \\
\hline
\end{tabular}

Berdasarkan hasil pengujian normalitas, data postes dari kelas eksperimen berasal dari populasi yang tidak berdistribusi normal. Oleh karena itu, maka uji hipotesis perbedaan rerata skor postes dilakukan dengan uji nonparametrik Mann-Whitney. Signifikansi uji Mann-Whitney yang dihasilkan dengan menggunakan software SPSS 20 adalah sig. (1-pihak). Hasil perhitungan uji perbedaan rerata disajikan pada Tabel 3.

Tabel 3. Uji Pihak Kanan Data Postes

Kemampuan Berpikir Kreatif Matematis

\begin{tabular}{ccccc}
\hline Kelas & \multicolumn{2}{c}{ Rerata } & \multicolumn{2}{c}{ Sig. } \\
& Rank & Postes & $\begin{array}{c}\text { Mann-Whitney } \\
\text { (1-pihak) }\end{array}$ & Kesimpulan \\
\hline Eksperimen & 44,19 & 9,70 & 0,002 & $\mathrm{H}_{o}$ Ditolak \\
Kontrol & 30,00 & 7,84 & & \\
\hline
\end{tabular}


Berdasarkan Tabel 3 di atas, dapat dilihat bahwa nilai signifikansi (1-pihak) uji Mann-Whitney dari data postes 0,002. Nilai signifikansi yang dihasilkan dari uji pihak kanan kemampuan berpikir kreatif matematis ini lebih kecil dari 0,05. Oleh karena itu, Ho ditolak. Hal ini berarti pada tingkat kepercayaan 95\%, terdapat perbedaan pencapaian kemampuan berpikir kreatif matematis siswa antara kelas ekperimen dan kontrol. Kemudian, dengan memperhatikan nilai rerata, diperoleh kesimpulan bahwa siswa yang memperoleh pembelajaran inkuiri berbantuan software Geogebra lebih baik daripada siswa yang memperoleh pembelajaran konvensional.

Untuk mengetahui apakah peningkatan kemampuan berpikir kreatif matematis siswa yang memperoleh pembelajaran inkuiri berbantuan software Geogebra (eksperimen) lebih baik daripada siswa yang memperoleh pembelajaran konvensional (kontrol), perlu dilakukan pengujian perbedaan rerata skor $\mathrm{N}$-gain dengan uji independent sample t-test. Sedangkan untuk mengetahui apakah terdapat peningkatan kemampuan berpikir kreatif matematis siswa yang mendapat pembelajaran inkuiri berbantuan software Geogebra dan siswa yang mendapat pembelajaran konvensional ditinjau berdasarkan kemampuan awal matematis (tinggi, sedang, dan rendah) perlu dilakukan pengujian perbedaan rataan skor $\mathrm{N}$ gain dengan uji nonparametrik Mann-Whitney. Uji normalitas skor N-gain kemampuan berpikir kreatif matematis menggunakan uji Kolmogorov-Smirnov. Hasil perhitungan uji normalitas skor $\mathrm{N}$-gain kelas eksperimen dan kontrol dapat dilihat pada tabel berikut.

Tabel 4. Uji Normalitas Skor N-gain Kemampuan Berpikir Kreatif Matematis

\begin{tabular}{cccl}
\hline \multirow{2}{*}{ Kelas } & \multicolumn{2}{c}{ Kolmogorov-Smirnov } & \multicolumn{1}{c}{ Kesimpulan } \\
& Sig. & Ket. & \\
\hline Ekesperimen & 0,008 & $\mathrm{H}_{\mathrm{o}}$ Ditolak & Tidak Berdistribusi Normal \\
Kontrol & 0,200 & $\mathrm{H}_{\mathrm{o}}$ Diterima & Berdistribusi Normal \\
\hline
\end{tabular}

Karena skor n-gain secara keseluruhan tidak berdsitribusi normal selanjutnya dilakukan uji Mann-Whitney. Berdasarkan hasil uji normalitas yang telah dilakukan sebelumnya diperoleh kesimpulan bahwa skor $\mathrm{N}$-gain secara keseluruhan tidak berdistribusi normal. Selanjutnya untuk membuktikan bahwa skor N-gain kemampuan berpikir kreatif matematis siswa secara keseluruhan dilakukan uji perbedaan rerata skor $\mathrm{N}$ gain dan Mann-Whitney $\mathrm{U}$ berada pada kategori baik. Hasil pengolahan data uji non parametrik Mann-Whitney U dengan bantuan SPSS 20.0 for windows disajikan pada tabel berikut.

Tabel 5. Uji Pihak Kanan N-gain Kemampuan Berpikir Kreatif Matematis

\begin{tabular}{|c|c|c|c|c|c|}
\hline \multirow{2}{*}{ Kelas } & \multicolumn{2}{|c|}{ Rerata } & \multirow{2}{*}{ Uji } & \multirow{2}{*}{ Sig. } & \multirow{2}{*}{ Но } \\
\hline & Rank & N-Gain & & & \\
\hline $\begin{array}{c}\text { Eksperimen } \\
\text { Kontrol }\end{array}$ & $\begin{array}{l}24,98 \\
14,76 \\
\end{array}$ & $\begin{array}{l}0,41 \\
0,23 \\
\end{array}$ & Mann-Whitney & 0,0025 & Ditolak \\
\hline
\end{tabular}

Dengan memperhatikan rerata n-gain, peningkatan kemampuan berpikir kreatif matematis siswa kelas eksperimen lebih baik daripada kelas kontrol ditinjau dari keseluruhan ini juga terlihat nilai sginifikansi lebih kecil dari 0,05 berarti Ho ditolak, dengan kata lain terdapat perbedaan secara signifikan. Berdasarkan analisis data n-gain di atas pada tabel 5 diperoleh hasil bahwa peningkatan kemampuan berpikir kreatif matematis yang mendapat pembelajaran inkuiri berbantuan software Geogebra lebih baik daripada siswa yang mendapatkan pembelajaran konvensional. 


\section{Pembahasan}

Dalam penelitian ini menggunakan dua model pembelajaran yaitu inkuiri berbantuan software Geogebra dan pembelajaran konvensional. Berdasarkan hasil penelitian diperoleh bahwa hasil pembelajaran inkuiri berbantuan software Geogebra dapat meningkatkan kemampuan berpikir kreatif matematis siswa. Hal ini dibuktikan dengan rerata $\mathrm{n}$-gain kemampuan berpikir kreatif matematis siswa sebesar 0,41 lebih baik daripada rerata n-gain kemampuan berpikir kreatif matematis siswa yang memperoleh pembelajaran konvensional sebesar 0,23. Meskipun klasifikasi peningkatan kemampuan berpikir kreatif matematis siswa belum mencapa tinggi, namun berdasarkan uji statistik diperoleh fakta bahwa pencapaian dan peningkatan kemampuan berpikir kreatif matematis siswa yang memperoleh pembelajaran inkuiri berbantuan software Geogebra lebih baik daripada siswa yang memperoleh pembelajaran konvensional.

Hasil penelitian yang telah diperoleh baik dari uji statistik dapat dikatakan bahwa model pembelajaran inkuiri berbantuan software Geogebra memberikan konstribusi yang baik dalam meningkatkan kemampuan berpikir kreatif matematis siswa. Sehingga, bisa dikatakan bahwa pembelajaran inkuiri berbantuan software Geogebra memiliki peran yang lebih baik dalam hal meningkatkan kemampuan matematis siswa.

Kemampuan berpikir kreatif matematis merupakan kemampuan tingkat tinggi yang terdiri dari empat indikator yaitu fluency, flexibility, originality, dan elaboration. Dalam pembelajaran inkuiri berbantuan software Geogebra kemampuan berpikir kreatif matematis siswa sangat ditekankan pada tahap processing dan creating. Tahap processing memotivasi siswa dalam proses menyelesaikan masalah atau materi pembelajaran, sehingga siswa termotivasi dalam melakukan tahap creating. Hal tersebut memfasilitasi siswa dalam mengembangkan kemampuan berpikir kreatif matematis. Tahap creating siswa mengatur informasi yang dimilikinya, dan kreatif dalam menentukan dan menyelesaikan masalah serta merevisi atau mengubah hal-hal yang diperlukan, sehingga dapat meningkatkan kemampuan berpikir kreatif matematisnya.

Pembelajaran inkuiri berbantuan software Geogebra dapat memfasilitasi kemampuan berpikir kreatif matematis matematis siswa. Hal ini sejalan dengan Dahar (1988) menyatakan bahwa pembelajaran penemuan meningkatkan kemampuan berpikir kreatif matematis siswa. Hasil ini juga sejalan dengan hasil penelitian Gani (2007) yang menyimpulkan bahwa pembelajaran inkuiri berbantuan software Geogebra dapat meningkatkan kemampuan pemahaman dan pemecahan masalah matematis siswa. Pembelajaran inkuiri berbantuan software Geogebra memberikan dampak yang baik untuk disposisi berpikir kreatif matematis siswa.

Tujuan dari penelitian ini adalah untuk mengetahui pencapaian dan peningkatan kemampuan berpikir kreatif matematis siswa yang memperoleh pembelajaran inkuiri berbantuan software Geogebra lebih baik dibandingkan dengan siswa yang memperoleh pembelajaran konvensional. Berdasarkan analisis data skor pretes kemampuan berpikir kreatif matematis antara kelas eksperimen dan kelas kontrol tidak berbeda secara signifikan. Hal ini dapat dilihat dari perolehan rerata skor pretes kelas eksperimen yaitu 5,35 , sedangkan perolehan skor pretes kelas kontrol yaitu 5,23. Dari kedua kelas tersebut terlihat rerata yang berbeda walau tidak signifikan, namun setelah dilakukan uji perbedaan rerata skor pretes kelas eksperimen dan kelas kontrol menunjukkan tidak terdapat perbedaan signifikan antara skor pretes kemampuan berpikir kreatif matematis siswa yang memperoleh pembelajaran inkuiri berbantuan software Geogebra dengan siswa yang memperoleh pembelajaran konvensional.

Setelah pembelajaran, skor postes siswa kelas eksperimen mencapai 9,70 dan memperoleh peningkatan 0,41 yang tergolong sedang, begitu juga siswa kelas kontrol yang 
mencapai 7,84 dan memperoleh peningkatan 0,23 yang tergolong sedang. Jika dilihat dari selisih perolehan rerata postes dan $\mathrm{N}$-gain, maka pencapaian dan peningkatan kemampuan berpikir kreatif matematis siswa yang pembelajarannya memperoleh pembelajaran inkuiri berbantuan software Geogebra lebih baik dibanding siswa yang memperoleh pembelajaran konvensional. Dapat disimpulkan bahwa terdapat perbedaan peningkatan kemampuan berpikir kreatif siswa matematis siswa yang memperoleh pembelajaran inkuiri berbantuan software Geogebra dengan siswa yang memperoleh pembelajaran konvensional.

\section{Simpulan dan Saran}

Berdasarkan analisis data, hasil penelitian dan pembahasan yang telah ditemukan pada bab sebelumnya, diperoleh simpulan penelitian sebagai berikut: 1) Pencapaian dan peningkatan kemampuan berpikir kreatif matematis siswa yang belajar dengan pembelajaran inkuiri berbantuan software Geogebra lebih baik daripada siswa yang memperoleh pembelajaran konvensional. Rerata skor postes pada kelas inkuiri berbantuan software Geogebra dan konvensional yaitu 9,70 (60,63\%) dan 7,84 (49,01\%), dari rerata skor postes kemampuan berpikir kreatif matematis siswa inkuiri berbantuan software Geogebra lebih tinggi daripada kelas konvensional. Untuk n-gain kelas inkuiri berbantuan software Geogebra lebih tinggi daripada kelas konvensional yaitu masing-masing 0,41 berada dalam kategori sedang dan 0,23 berada dalam kategori rendah. Dan 2) kegiatan pembelajaran di kelas yang memperoleh pembelajaran inkuiri software Geogebra sudah terlaksana dengan baik. Walaupun pada awal pertemuan masih dibutuhkan waktu penyesuaian, akan tetapi pada pertemuan selanjutnya pembelajaran berlangsung sesuai dengan langkah-langkah yang telah ditentukan.

Berdasarkan analisis dan pembahasan hasil penelitian, maka penulis mengemukakan beberapa saran sebagai berikut: 1) Berdasarkan hasil penelitian, secara keseluruhan pembelajaran inkuiri berbantuan software Geogebra memberikan pengaruh lebih baik untuk mengembangkan kemampuan berpikir kreatif matematis siswa. Oleh karena itu pembelajaran inkuiri model Alberta sebaiknya dijadikan alternatif pembelajaran dalam tujuan meningkatkan prestasi siswa baik itu kognitif maupun afektif. 2) Dalam menggunakan pembelajaran inkuiri berbantuan software Geogebra diperlukan persiapan yang matang agar proses pembelajaran dapat berjalan lancar. Dan 3)Kemampuan matematis yang diteliti pada pembelajaran inkuiri berbantuan software Geogebra kali ini adalah kemampuan berpikir kreatif matematis. Untuk peneliti selanjutnya sebaiknya meneliti kemampuan matematis yang lainnya, seperti kemampuan representasi, berfikir kritis dan metakognisi.

\section{Referensi}

Adnan Akkaya, et al. (2011). Using Dynamic Software in Teaching of the Symmetry in Analytic Geometry: The Case of Geogebra. Procedia Social and Behavioral Sciences 15. (pp.2540-2544).

Alberta L. (2002). Mathematics Preparation 10 Programs of Studies. Edmonton, AB: Alberta Learning.[Online]. Tersedia: http://www.learning.gov.ab.ac/k_12/curriculum/bySubject/math/mathprep10.pdf. [12 Mei 2017]. 
Alberta L. (2004) focus On Inquiry: A Teacher's Guided to Implementing Inquiry-based Learning. [Online]. Tersedia: http://www.education.alberta.ca/media/313361/focusoninquiry.pdf. [12 Mei 2017].

Apiati, V. (2012). Peningkatan Kemampuan Pemahaman dan Pemecahan Masalah Matematis Siswa Melalui Metode Inkuiri Berbantuan software Geogebra software Geogebra. Tesis. PPS UPI: Tidak diterbitkan.

Craft, A. (2001). An Analysis of Research And Literature On Creativity Education. [Online].Tersedia:

http://www.euvonal.hu/images/creativity_report.pdf. [20 Mei 2017].

Hastuti, Sri. 2009. Prosiding Seminar Nasional Peneltian, Pendidikan dan Penerapan MIPA Fakultas MIPA, Universitas Negeri Yogyakarta. Online. Di unggah pada 5 Mei 2017.

Hamnuri. 2012. Strategi Pembelajaran. Yogyakarta: Insan Mandiri.

Hohenwarter, M., et al. (2008). Teaching and Learning Calculus with Free Dynamic Mathematics Software GeoGebra. Tersedia; http://www. publications.uni.lu/record/2718/files/ICME11-TSG16.pdf. [15 Mei 2010].

Hohenwarter, M., et al. (2004). Combination of Dynamic Geometry, Algebra, and Calculus in the Software System Geogebra. Tersedia: www.geogebra.org/publications/pecs_2004.pdf. [16 Mei 2017].

Hendrayana, A. (2008). Pengembangan Multimedia Interaktif Untuk Meningkatkan Kemampuan Berpikir Kritis dan Kreatif Siswa SMP dalam Matematika. Tesis. SPS UPI: Tidak diterbitkan.

Kartini. (2011). Peningkatan Kemampuan Berpikir Kritis dan Kreatif serta Belief Matematis Siswa Sekolah Menengah Atas Melalui Pembelajaran Inkuiri Berbantuan software Geogebra software Geogebra. Disertasi. SPS UPI: Tidak diterbitkan.

LTSIN. (2004). Learning Thinking. Scotland: Learning and teaching Scotland.

Mahmudi, A. (2010). Pengaruh Pembelajaran dengan Strategi MHM Berbasis Masalah Terhadap Kemampuan Berpikir Kreatif, Kemampuan Pemecahan Masalah, dan Disposisi Matematis, serta Persepsi Terhadap Kreativitas. Disertasi. SPS UPI:Tidak diterbitkan.

Mahmudi, A. (2010). Mengukur Kemampuan Berpikir Kreatif Matematis. Makalah Disajikan pada Konferensi Nasional Matematika XV UNIMA Manado, 30 Juli 2010.

[Online]Tersedia: http://staff.uny.ac.id/sites/default/files/penelitian/AliMahmudi, S.Pd,M.Pd,Dr./Makalah14ALIUNYYogyaforKNMUNIMA_MengukurKemampua nBerpikirKreatif_pdf.[17 Mei 2017]. 
Mulyana, T. (2008). Pembelajaran Analitik Sintetik Untuk Meningkatkan Kemampuan Berpikir Kritis dan Kreatif Matematik Siswa Sekolah Menengah Atas. Disertasi. SPS UPI: Tidak diterbitkan.

Munandar, S.C. U. (1999). Kreativitas dan Keterbakatan Strategi Mewujudkan Potensi Kreatif dan Bakat. Jakarta: PT Gramedia Utama.

Munandar, S.C. U. (1999). Mengembangkan Bakat dan Kreativitas Anak Sekolah. Petunjuk Bagi Para Guru dan Orang Tua. Jakarta: PT Gramedia Widiasarana Indonesia.

Park. (2004). The Effects Of Divergent Production Activities With Math Inquiry And Think Aloud Of Students With Math Difficulty. Disertasi pada texas A\&M University. [Online]. Tersedia: repository.tamu.edu/bitstream/etd-tamu-2004A-EPSY-Park1.pdf. [30 Mei 2017].

Pehkonen, E. (1997). The State-of-Art in Mathematical Creativity. Volume 29 (June 1997) Number 3. Electronic Edition ISSN 1615-679X.[Online]. Tersedia: http://www.fiz.karlsruhe.de/fiz/publications/zdmZDM. [19 Mei 2017].

Türkan, et al (2011) Analytic Analysis of Lines with Dynamic Mathematical Software. Procedia Social and Behavioral Sciences 15. (pp.2505-2509).

Yilmaz Zengin, et al. (2011). The effect of dynamic mathematics software geogebra on student achievement in teaching of trigonometry. Procedia Social and Behavioral Sciences 31. (pp.183-187). 